\title{
M.A.Enixiна
}

\section{ДЕФІНІЦІЙНИЙ АНАЛІЗ ПОНЯТТЯ «ВЗАЕМОДІЯ» У ФІЛОСОФСЬКОМУ ТА СОЦІОЛОГІЧНОМУ ВИМІРІ}

У статті визначено місие та роль партнерської взаємодї, яка $\epsilon$ однією з ключових засад забезпечення якості реформування Нової украӥнської школи. Метою статті $е$ здійснення дефініційного аналізу поняття «взаємодія». $У$ статті використані теоретичні методи дослідження: аналіз, синтез, порівняння, систематизація, узагальнення. Розглянуто категорію «взаємодія» у філософському та сочіологічному аспектах, визначено сутність досліджувальної категорії, здійснено аналіз наукових поглядів зарубіжних $i$ вітчизняних філософрів та соціологів на сутність явища взаємодіі. Запропоновані філософські теорії демонструють, щзо категорія «взаємодія» відображає процеси впливу різних об'єктів один на одного, їх взаємну обумовленість, зміну стану, взаємоперехід, а також породження одним об'єктом іншого; серед загальних ознак взаємодіі як реального явища виділені наступні: цілісність, одночасність існування об'єктів, взаємозумовленість змін сторін, внутрішня самоактивність суб'єктів. Визначено, щзо кожному рівню розвитку матерї відповідає свій тип взаємодї; з ускладненням форм руху ускладнюється $і$ тип взаємодї. Аналіз поглядів сочіологів на феномен «взаємодія» дозволив виділити наступні сутнісні характеристики: пізнання людиною самої себе відбувається в актах взаємодї; взаємодія є механізмом самовдосконалення $i$ саморозвитку, а також взаємодія допомагає будувати відносини з іншими людьми і підвищувати якість сочіального середовищуа. Автор приходить до висновку, щзо партнерська взаємодія є частиною загальної взаємодії, яка належить до міждисичплінарних категорій. Визначено, щзо кожна наукова галузь у філософському та соціологічному просторі пропонує свої класифікацї, види та форми взаємодї, які не суперечать, а лиме доповнюють одна одну. Встановлено, що філософське поняття взаємодії тісно переплітається з поняттям взаємодї в соиіологї $і$ є базовим для всіх соиіальних наук (серед яких існує $і$ педагогіка), оскільки людина з самого народження є невід 'ємною частиною взаємопов 'язаних одиниць.

Ключові слова: взаємодія, партнерська взаємодія, педагогіка партнерства, партнерство, взаємозв'язок, Нова украӥнська школа, філософія, сочуіологія. 
Yepikhina M. A. Definitive analysis of the concept of "interaction»" in the philosophical and sociological dimension. The article identifies the place and role of partnership, which is one of the key principles of ensuring the quality of the New Ukrainian School reforming. The purpose of the article is to perform a definitive analysis of the concept of «interaction». Theoretical research methods are used in the article: analysis, synthesis, comparison, systematization, generalization. The category "interaction» in the philosophical and sociological aspects is considered, the essence of the research category is determined, the scientific views of foreign and domestic philosophers and sociologists on the essence of the interaction phenomenon are analyzed. The proposed philosophical theories demonstrate that the category «interaction» reflects the processes of influence of different objects on each other, their mutual conditionality, change of state, mutual transition, as well as the one object creation of another; the common features of interaction as a real phenomenon are the following: integrity, simultaneity of existence of objects, interdependence of changes of parties, internal self-activity of subjects. It is determined that each level of matter development has its own type of interaction; the type of interaction is complicated with the complexity of the movement forms. The analysis of sociologists' views on the "interaction» phenomenon made it possible to distinguish the following essential characteristics: a person's self-knowledge takes place in acts of interaction; interaction is a mechanism for self-improvement and self-development, and interaction helps build relationships with others and improve the quality of the social environment. It is established that partnership interaction is part of a general interaction that belongs to interdisciplinary categories. The author determines that each scientific branch in philosophical and sociological space offers its classifications, types and forms of interaction, which do not contradict, but complement each other only. It is established that the philosophical concept of interaction is closely intertwined with the concept of interaction in sociology and is the basis for all social sciences (including pedagogy), since the person from birth is an integral part of interconnected units.

Keywords: interaction, partnership interaction, partnership pedagogy, partnership, interconnection, New Ukrainian School, philosophy, sociology.

Вступ. Проблема становлення партнерських відносин набуває особливої вагомості на сучасному етапі розвитку суспільства. Як відзначає Н. Пов'якель, партнерство у стосунках між людьми $є$ гарантом їх продуктивної взаємодії, одним із гнучких способів конструктивного вирішення проблем, а також психологічним показником рівня особистісного і професійного зростання людини (Poviakel, 2010). Об'єктивна необхідність посилення партнерських зв'язків у різних ланках суспільного життя зумовлює потребу у фахівцях, які вміють співпрацювати, встановлювати 
ділові стосунки 3 партнерами, професійно спілкуватись, долати комунікативні труднощі тощо.

За експертними оцінками, які були озвучені на початку 2016 р. на World Economic Forum, у 2020 році для успішного працевлаштування будуть потрібні такі навички: уміння вирішувати складні завдання; критичне мислення; креативність; управління людьми, навички координацї та взаємодіi;; емоційний інтелект; судження і прийняття рішень; клієнтоорієнтованість, уміння вести переговори; когнітивна гнучкість (Vektory metodychnoi roboty (poradnyk do analizu ta planuvannia roboty PNMK (MO) na 2017-2018 n.r.), 2016).

У Концепції Нової української школи (2018) наголошено на розвитку суб’єктності учня, необхідності оволодіння учнем способами навчальної діяльності, досвіді взаємодї з іниими людьми. «Педагогіка партнерства»є грунтовною ідеєю, на якій базується Нова українська школа, в основі якої спілкування, взаємодія та співпрачя між учителем, учнем і батьками. Учні, батьки та вчителі, об’єднані спільними цілями та прагненнями, є добровільними та зацікавленими однодумцями, рівноправними учасниками освітнього процесу, відповідальними за результат. Цінності та принципи педагогіки партнерства закладені в основі стандарту освіти, оновленій системі професійного розвитку вчителя, сучасній державній освітній та кадровій політиці. Отже, однією 3 ключових засад забезпечення якості реформування української школи $\epsilon$ партнерська взаємодія між учнем, учителем та батьками (Reforma zahalnoi serednoi osvity: Nova ukrainska shkola, 2018).

Останнім часом партнерська взаємодія в педагогіці дедалі стає все більш актуальною й розробляється в різних аспектах. Значно збільшується кількість психолого-педагогічних розвідок щодо вивчення даного феномену, відбувається активний пошук нових підходів щодо розуміння сутності взаємодії, використовується більш широке коле теорій та концепцій із різних сфер життя суспільства.

Мета та завдання. Метою даної статті $€$ здійснення дефініційного аналізу поняття «взаємодія».

Методи дослідження. У процесі наукового пошуку використовувались такі загальнонаукові методи, як: аналіз (філософської, соціологічної, психолого-педагогічної літератури, інформаційних джерел із проблеми дослідження), дефініційний аналіз (3 метою визначення сутності досліджувальної категорії), синтез, порівняння, систематизація наукових 
джерел (для виявлення стану розробленості проблеми), узагальнення (для визначення провідної категорії дослідження).

Результати. У філософському енциклопедичному словнику взаємодія розглядається як філософська категорія, яка відображає особливий тип відношення між об’єктами, при якому кожний із об'єктів діє (впливає) на інші об’єкти, приводячи до їх зміни, і водночас зазнає дії (впливу) з боку кожного з цих об'єктів, що, в свою чергу, зумовлює зміну його стану (Filosofskyi entsyklopedychnyi slovnyk, 2002).

Категорія взаємодії була предметом дослідження Анаксагора (загальний закон взаємодії матеріï), Аристотеля (зміни взаємодіючих тіл як визначальної риси взаємодіï), Платона (тезис про те, що про існування речі можна судити за їх здатності або впливати на щось, або відчувати хоч найменший вплив), Ф. Бекона ( досліджує роль середовища як посередника в контактах між діючими та тими, що піддаються впливу об'єктами), Г. Гегеля, I. Канта, Ф. Шеллінга та ін. (дослідження категорії взаємодії у філософії, яке пов'язане з вивченням взаємодії та взаємозалежності між взаємодіючими об'єктами) та ін.

У XIX-XX ст. взаємодія досліджувалась такими філософами як В. Вернадський, В. Соловйов, П. Флоренський, К. Циолковський, А. Чижевський, К. Кедров та ін.

Проте нашу увагу привертає погляд філософії на взаємодію людини 3 людиною. Ідея про те, що особистість не можна пізнати, розглядаючи іiі ізольовано, поза взаємодії 3 іншими людьми $є$ однією 3 провідних ідей екзистенціоналізму. При цьому людина розглядається як ціле процесу постійної зміни і розвитку (В. Андрущенко, В. Воронкова, В. Кремень, К. Ясперс та ін. ).

Досліджуючи філософсько-методологічне підгрунтя феномену педагогічної взаємодії, І. Хомич відзначає, що взаємодію в людському соціумі можна визначити як складний процес, під час якого суб'єкти взаємозмінюються, що зумовлено їх взаємним впливом. Взаємодія має безперервний характер. Вона являє собою дії активних суб'єктів, які мають задану ціль. Взаємодія змінює дійсність і потребує творчого підходу (Khomych, 2014).

Є. Коротаєва, вважає, що існує особлива філософія взаємодій, яка прагне пізнати «незбагненний» світ у його багатовимірності. Філософські теорії, на думку вченого, демонструють, що існує особлива ієрархія взаємодій. Як стверджує Є. Коротаєва, між первинними і опосередкованими 
взаємодіями наявний прямий або опосередкований зв'язок, заснований на причинності всього сущого, запереченні i тотожність, співвідношенні унікальності і цілісності, кількості і якості, свободи і необхідності тощо (Korotaeva, 1999).

В. Гришко-Дунаєвська визначає взаємодію як матеріальний процес, який супроводжується передачею матерії, руху та інформації. На думку вченого, взаємодія відносна, здійснюється з певною швидкістю і в певному просторі - часі. Саме через взаємодію людина пізнає природні та суспільні явища, закономірності, процеси, орієнтується в оточуючій реальності, визначає способи мислення та поведінки. Крім того, як відзначає вчений, 3 цим поняттям пов'язана також потреба людини у спілкуванні, навчанні, освіті, особистісному розвитку (Hrishko-Dunaievska, 2015).

О. Кваша категорію взаємодії розглядає як фундаментальну, ключову для глибокого та конструктивного розуміння інших категорій, таких як «рух», «детермінація», «причина», «зв’язок», «вплив», «дія» та ін. На думку вченого, категорії «причина» і «дія» логічно відтворюють один з моментів руху і взаємодії речей на сутнісному рівні. Як відзначає дослідник, причина, переходячи в дію, відроджується у ній i навпаки. У цьому взаємному обумовленні причина i дія зливаються у взаємодію; односпрямована детермінація переходить у симетричну, взаємну детермінацію. Відповідно, речі виступають одночасно як активні та пасивні, діють зовні і як такі, що відчувають дію на собі, як рушійні та приведені в рух (але в різних взаємозв’язках). Причинність виступає як взаємна причинність, взаємодія, як виявлення саморуху матерії. Тому слід погодитись із вченими у тому, що пізнання причинності веде до розкриття сутнісного аспекту взаємодії, яка $\epsilon$ двостороннім або навіть багатостороннім процесом, який має взаємний характер (Kvasha, 2012).

Аналізуючи характерні категоріальні ознаки «взаємодії», Н. Шигонська відзначає, що сучасна наукова думка визначає взаємодію як філософську категорію, що відображає процеси взаємовпливу різних об’єктів, їх взаємозв’язок, взаємообумовленість, взаємоперехід, а також породження одним об’єктом іншого. Це форма зв’язку тіл або явищ, що здійснюється в їх взаємній зміні. Дослідниця наголошує, що у суспільних науках існують різні трактування сутності категорії «взаємодія». Так, ряд філософів визначають взаємодію як «процес», при якому індивіди або групи в ході комунікації своєю поведінкою впливають на інших індивідів або інші групи, при цьому викликаючи зворотні реакції (Г. Осіпов, Б. Кедрів, Е. Евладова, А. Радугін, 
C. Родіонова). Н. Шигонська доводить, що доволі часто, взаємодію характеризують як «вплив», який систематично здійснюється суб'єктами взаємодії, при якому реалізується їх соціальна дія, досягаються пристосування дій одного до дій іншого, спільність у розумінні ситуації, смислу дій і певний ступінь солідарності або згоди між ними (Є. Рогов, В. Горбатенко, І. Цимбалюк, Г. Ложкін, В. Спасєнніков, В. Комаровська, Ю. Шемшученко). На думку Н Шигонської, різноманітність поглядів щодо трактування процесу між суб'єктами, що беруть участь у взаємодії закладена в самому терміні, який одночасно означає взаємний вплив і діяльність (Shyhonska, 2008).

Що стосується соціології, то перевага у категорії «взаємодія» надається дослідженню механізмів впливу даної категорії на процес розвитку як суспільства у цілому, так й індивіду зокрема. Оскільки освітній процес належить до категорії соціальних, то аналіз соціологічних досліджень щодо взаємодії індивіда з оточуючою дійсністю є очевидним.

У американській соціології актуальними сьогодні $\epsilon$ концепції взаємодії Дж. Г. Мида, Г. Блума, А. Шюца. Досліджуючи соціальний акт як взаємодію, Дж. Г. Мид надає пріоритет етапності його розвитку та виділяє чотири стадії: імпульс, перцепцію, маніпуляцію, консумацію. На думку вченого, послідовне пересування індивіда за цими стадіями пов'язане з його переходом на новий етап розвитку (Kozhushko, 2013).

Дещо подібними є погляди Г. Блумера, який вважає, що суб'єкт, який вступає у взаємодію з оточуючими, здатен не тільки змінити конкретні обставини, проявляючи себе автором того чи іншого соціального акту, а й знов створити самого себе в процесі його здійснення (Fotev, 1994).

А. Шюц вводить поняття «біографічна ситуація» як індивідуальну транскрипцію біологічних і соціокультурних факторів, які впливають на людину. Вчений відзначає, що біографічна ситуація, яка постійно змінюється у зв'язку з дорослішанням суб'єкта, є основною, оскільки забезпечує розуміння і інтерпретацію кожної іншої людини, кожної соціальної взаємодії, в якій вона бере участь (Dobren'kova, 1994).

Сьогодні існує чимало вітчизняних наукових досліджень, які присвячено аналізу соціальної взаємодії.

Зокрема, К. Ібрагімова, вивчаючи поняття соціальної взаємодії, зазначає, що соціальна взаємодія - це, насамперед, якісний процес безпосередньої дії людей один на одного, що породжує їх взаємний зв'язок. Дослідниця підкреслює, що соціальна взаємодія сприяє не лише вирішенню 
чисто утилітарних завдань, але - i духовному взаємозбагаченню, оскільки саме в процесі спільної діяльності і спілкування найбільш рельєфно виявляється як професійна, так і соціальна дієздатність кожної конкретної людини. К. Ібрагімова відзначає, що соціальна взаємодія буває випадковою, тимчасовою, стійкою, приватною і публічною; особистісною і мовленнєвою; формальною і неформальною. Одним із виявів соціальної взаємодії, на думку дослідниці, є зв’язок (Ibrahimova, 2013).

О. Яструб, досліджуючи категорію «взаємодія» у контексті культури міжособистісної взаємодії, відзначає, що взаємодія в соціології - складова частина та форма вияву загальної, універсальної взаємодії. На думку дослідниці, суспільство - це система реальних зв’язків і взаємодій людини з іншими людьми, соціальними групами, сукупність усіх соціальних стосунків - опосередкованих і безпосередніх, свідомих і неусвідомлених. У процесі взаємодії відбувається обмін діями, зароджуються спорідненість, координація дій обох суб'єктів, стійкість їх інтересів, планування спільної діяльності, розподіл функцій тощо. За допомогою дій відбуваються взаємне регулювання, взаємний контроль, взаємовплив, взаємодопомога. Це означає участь кожного учасника взаємодії в розв’язанні спільного завдання 3 відповідним коригуванням своїх дій, урахуванням попереднього досвіду, активізацією власних здібностей і можливостей партнера (Iastrub, 2014).

Цінним для нас $є$ дослідження С. Кожушко, яка здійснила аналіз наукових поглядів соціологів на сутність явища взаємодії. Дослідниця відзначає, що у науковому обігу соціологів, феномен «взаємодія» визначається як процес безпосереднього або опосередкованого впливу суб'єктів один на одного, який породжує причинну зумовленість їх дій i взаємозв’язок. Цей процес, на думку автора, потребує: активності та взаємної спрямованості дій тих людей, які беруть у ньому участь; взаємний обмін діями, організацію людьми взаємних дій, спрямованих на реалізацію спільної діяльності; обмін почуттями, ідеями, вольовими імпульсами (Kozhushko, 2013).

На основі аналізу теоретичних конструкцій соціологів (Р. Бейлс, М. Вебер, Т. Парсон, П. Сорокін, Дж. Хоманс, Я. Щепанський та ін.), які досліджували феномен «взаємодія», С. Кожушко приходить до висновку, що переважна більшість соціологів уважають, що взаємодія особистості 3 іншими (на рівні зв'язку «Я - Ти», «Я - Ми», «Я - Вони») стимулює комунікативні процеси, сприяє формуванню високого рівня реалізму, відповідності, ціннісно-світоглядної орієнтації, мудрості в соціальній 
стратегії. Автор відзначає, що продуктивність взаємовпливу зростає, якщо враховувати не лише індивідуальні інтереси, стиль мислення людини в процесі взаємодії, але й іï організованість, нормативне зміщення, упорядкування зв'язків. Саме соціальні норми забезпечують узгодженість дій, регулювання поведінки, соціальний контроль, захист певних інтересів, відображають загальні вимоги суспільства до поведінки особи, групи у взаємовідносинах один з одним, соціальними інститутами, суспільством. Як відзначає дослідниця, науковцями також сформульовано вимоги до суб'єктів взаємодії (емпатія, саморефлексія дій, самоконтроль, прагнення до самовдосконалення, високий моральний, культурний рівень) (Kozhushko, 2013).

Обговорення. Наша позиція щодо трактування феномену взаємодії пов'язана 3 іiї розглядом як процесу безпосередньої або опосередкованої взаємодії суб'єктів, який породжує взаємну зумовленість і зв'язок. Особливістю взаємодії є іiі причинна детермінація: кожна з взаємодіючих сторін виступає як причина іншої i, одночасного, як наслідок впливу протилежної сторони.

Висновки. Підсумовуючи відзначимо, що запропонований дефініційний аналіз поняття «взаємодія» засвідчив варіативність підходів щодо визначення досліджуваного поняття. Подані до розгляду дефініції взаємодії не взаємовиключають, а органічно доповнюють одна одну, що, в свою чергу, дозволяє розглянути дане поняття з різних точок зору.

Проведена аналітична робота уможливила виокремлення таких ознак взаємодії, як-от:

- наявність двох матеріальних систем, які здатні до самоактивності та мають спільні точки дотику;

- взаємодія завжди цілісна, жодна з їі форм не може існувати у відриві від інших;

- ставлення людини до іншої людини має двосторонню спрямованість: активна дія однієї з них, спрямована на іншу, «віддзеркалюється» від неї і тим самим перетворюється в дію, спрямовану через іншого на себе.

Подальшої наукової розвідки потребує вивчення підходів до тлумачення поняття «взаємодія» у психології та педагогіці.

\section{ЛІТЕРАТУРА:}

Вектори методичної роботи (порадник до аналізу та планування роботи ПНМК (МО) на 2017-2018 н.р.) [Електронний ресурс]. Режим доступу: https://dobrmetod.jimdo.com 
Грішко-Дунаєвська В. А. Основні підходи до вивчення проблеми взаємодії в науковопсихологічній літературі [Електронний ресурс]. Режим доступу: http://nbuv.gov.ua/UJRN/znpnapv_pn_2015_1_7

Ібрагімова К. О. Дефініція поняття соціальна взаємодія, іiї види та основні теорії [Електронний ресурс]. Режим доступу: http://nbuv.gov.ua/UJRN/Pipo_2013_40-41_48

Кваша О. О. Зміст і значення понять «взаємодія» та «система» у філософських і правових досліджень [Електронний ресурс]. Режим доступу: http://dspace.nbuv.gov.ua/bitstream/handle/123456789/64055/06Kvasha.pdf? sequence $=1$

Кожушко С. П. Соціологічні аспекти проблеми взаємодії [Електронний ресурс]. Режим доступу: https://repository.sspu.sumy.ua/bitstream/123456789/2861/1/Sotsiolohichni\%20aspekty \%20problemy\%20vzaiemodii.pdf

Коротаева Е.В. Педагогика взаимодействий: учеб. пособие. Екатеринбург: Урал. гос. пед. ун-т., 1999. 147 с.

Пов'якель Н. І. Психологічна готовність до партнерства як ознака психічного здоров'я особистості та умова превенції конфліктів. Міжнародний науковий форум: соиіологія, психологія, педагогіка, менеджмент. 2010. Вип. 2. С. 139-150.

Реформа загальної середньої освіти: Нова українська школа [Електронний ресурс]. Режим доступу: https://reforms.in.ua/sites/default/files/osvita.pdf

Современная американская социология: сб. стат. / под. ред. В. И. Добренькова. Москва: МГУ, 1994. 295 с.

Філософський енциклопедичний словник, Київ: Абрис, 2002. 741 с.

Фотев Г. Современная американская социология. Герберт Блумер: символический интеракционализм. Москва: МГУ, 1994. 295 с.

Хомич I. М. Філософське-методологічне підгрунтя феномену педагогічної взаємодії суб'єктів навчального процесу в системі сучасної мистецької освіти [Електронний peсурс]. Режим доступу: http://nbuv.gov.ua/UJRN/Nzped_2014_121_34

Шигонська Н. В.Філософський, психологічний, соціологічний та педагогічний аспекти сутності категорії «професійна взаємодія» [Електронний ресурс]. Режим доступу: http://eprints.zu.edu.ua/2919/1/35_42.pdf

Яструб О. Сутнісний аналіз поняття «культура міжособистісної взаємодії» [Електронний peсурс]. Режим доступу: http://nbuv.gov.ua/UJRN/Nvvnup_2014_8_20 (дата звернення: 19.11.2019).

\section{REFERENCES:}

Dobren'kova, V.Y. (Ed.). (1994). Sovremennaja amerikanskaja sociologija [Modern American Sociology]. Moskva: MGU (in Russian)

Filosofskyi entsyklopedychnyi slovnyk (2002). [Encyclopedic Dictionary of Philosophy]. Kyiv: Abrys (in Ukrainian)

Fotev, G. (1994) Sovremennaja amerikanskaja sociologija. Gerbert Blumer: simvolicheskij interakcionalizm [Modern American Sociology. Herbert Bloomer: Symbolic Interactionism]. Moskva: MGU (in Russian)

Hrishko-Dunaievska, V. A. Osnovni pidkhody do vyvchennia problemy vzaiemodii v naukovopsykholohichnii literaturi (2015). [The main approaches to the study of the problem of interaction in the scientific and psychological literature] Retrieved from http://nbuv.gov.ua/UJRN/znpnapv_pn_2015_1_7 (in Ukranian)

Iastrub, O. (2014). Sutnisnyi analiz poniattia «kultura mizhosobystisnoi vzaiemodii» [Substantial analysis of the concept of «culture of interpersonal interaction»] Retrieved from http://nbuv.gov.ua/UJRN/Nvvnup_2014_8_20 (in Ukranian) 
Ibrahimova, K. O. (2013) Definitsiia poniattia sotsialna vzaiemodiia, yii vydy ta osnovni teorii [The definition of social interaction, its types and basic theories] Retrieved from http://nbuv.gov.ua/UJRN/Pipo_2013_40-41_48 (in Ukranian)

Khomych, I. M. (2014). Filosofske-metodolohichne pidgruntia fenomenu pedahohichnoi vzaiemodii subiektiv navchalnoho protsesu $v$ systemi suchasnoi mystetskoi osvity [Philosophical and methodological basis of the phenomenon of pedagogical interaction of subjects of educational process in the system of contemporary art education] Retrieved from http://nbuv.gov.ua/UJRN/Nzped_2014_121_34 (in Ukranian)

Korotaeva, E.V. (1999) Pedagogika vzaimodejstvij: ucheb. posobie [Pedagogy of interactions: textbook. allowance]. Ekaterinburg: Ural. gos. ped. un-t (in Russian)

Kozhushko, S. P. (2013). Sotsiolohichni aspekty problemy vzaiemodii [Sociological aspects of the problem of interaction] Retrieved from https://repository.sspu.sumy.ua/bitstream/123456789/2861/1/Sotsiolohichni\%20aspekty $\% 20$ problemy\%20vzaiemodii.pdf (in Ukranian)

Kvasha, O. O. (2012). Zmist $i$ znachennia poniat «vzaiemodiia» ta «systema» u filosofskykh $i$ pravovykh doslidzhen [The content and meaning of the concepts of «interaction» and «system» in philosophical and legal studies] Retrieved from http://dspace.nbuv.gov.ua/bitstream/handle/123456789/64055/06Kvasha.pdf?sequence $=1$ (in Ukranian)

Poviakel, N. I. (2010) Psykholohichna hotovnist do partnerstva yak oznaka psykhichnoho zdorovia osobystosti ta umova preventsii konfliktiv [Psychological readiness for partnership as a sign of mental health of the individual and a condition for conflict prevention] Mizhnarodnyi naukovyi forum: sotsiolohiia, psykholohiia, pedahohika, menedzhment. Vyp. 2. P. 139-150 (in Ukrainian)

Reforma zahalnoi serednoi osvity: Nova ukrainska shkola (2018). [Reform of general secondary education: New Ukrainian School] Retrieved from https://reforms.in.ua/sites/default/files/osvita.pdf (in Ukranian)

Shyhonska, N. V. Filosofskyi, psykholohichnyi, sotsiolohichnyi ta pedahohichnyi aspekty sutnosti katehorii «profesiina vzaiemodiia» [Philosophical, psychological, sociological and pedagogical aspects of the essence of the category «professional interaction»] Retrieved from http://eprints.zu.edu.ua/2919/1/35_42.pdf (in Ukranian)

Vektory metodychnoi roboty (poradnyk do analizu ta planuvannia roboty PNMK (MO) na 2017-2018 n.r.) (2016). [Vectors of methodical work (advisor to the analysis and planning of work of PNMK (MO) for 2017-2018 years)] Retrieved from https://dobrmetod.jimdo.com (in Ukranian)

\section{Інформація про автора: \\ Єпіхіна Марина Анатоліївна: \\ ORCID:https://orcid.org/0000-0003-0199-}

8186, кандидат педагогічних наук, доцент кафедри дошкільної та початкової освіти навчально-наукового інституту педагогіки і психології Луганського національного університету імені Тараса Шевченка, пл. Гоголя, 1, м. Старобільськ, Україна, 92703.

\section{Information about the author:}

Yepikhina Maryna Anatoliivna:
ORCID:https://orcid.org/0000-0003-01998186 Candidate of Pedagogical Sciences, Associate Professor at the Department of Preschool and Primary Education, Luhansk Taras Shevchenko National University, Gogol Square, 1, Starobilsk, Ukraine, 92703.

e-mail: dewdrop@ukr.net 
Цитуйте цю статтю як: Спіхіна М.А. Дефініційний аналіз поняття «взаємодія» у філософському та соціологічному вимірі. Теорія та методика навчання та виховання. 2020. № 48. C.53-63.

DOI: https://doi.org/10.34142/23128046.2020.48.05

Дата надходження статті до редакції:

Стаття прийнята до друку: 